\title{
Composition of Rats Fed on Diets containing Wheat Flours of Different Percentage Extraction
}

\author{
BY E. B. SLACK \\ Lister Institute of Preventive Medicine, London, S.W. I
}

(Received 5 May 1948)

In the preceding paper by Chick \& Slack (1948), experiments are described in which the nutritive value of the proteins of wheaten flours of different percentage extraction rate was compared by the method of Osborne, Mendel \& Ferry (1919). Determination of the protein efficiency ratio (g. weight increase/g. of protein consumed, henceforth referred to as the P.E.R.) for the proteins of $70,80,85$ and $100 \%$ extraction flours, showed a superiority of about $20 \%$ for the protein of the wholemeal over that of the $70 \%$ flour. The values obtained for the 85 and $80 \%$ flours were intermediate but were closer respectively to those obtained for wholemeal and white flour.

This method of comparing the nutritive value of proteins has been criticized on several grounds, one of these, due to Mitchell (1924), being that the composition of the gain in weight is different in rats which grow at different rates. Mitchell argues that the weight gain in the more rapidly growing, and therefore larger, animals is partly due to a relatively greater deposition of fat in these than in the slower growing animals and therefore leads to an over-estimation of the nutritive value of the better quality proteins on which the quicker growing animals had been fed. MIcCollum \& Simmonds (1929) suggested that the gain in nitrogen, rather than the gain in body-weight/g. of protein ingested, might give a truer figure for the nutritive value of a protein, but this suggestion does not seem to have received much consideration. Since this method can be combined with a determination of P.E.R. it was thought worth while to apply it to the rats used by Chick \& Slack (1948) in their Exp. I. It was decided to determine not only the nitrogen content of the rats used in this experiment but also their content of fat, water and ash. From these figures for rats of different weights it was hoped to obtain definite information as to whether any significant error was involved in assessing the nutritive value of proteins by the simple measurement of P.E.R.

\section{EXPYRIMENTAL}

At the beginning of the experiment, when the average body-weight was $47 \mathrm{~g}$., a male and female rat were taken from each of the four litters used, killed by coal gas and weighed immediately to the nearest $0.1 \mathrm{~g}$. 'They were then opened, the alimentary tracts removed and the carcasses placed in large weighed crucibles and covered with pads of moist filter-paper to prevent loss of moisture. The stomach and intestine were slit open, the contents washed out and the empty gut was pressed in filter-paper to remove excess water, and added to the remainder of the carcass in the crucible. After 
again weighing to the nearest $0.1 \mathrm{~g}$. to obtain the 'empty' weight of the body, by which is meant the body-weight minus the contents of the gut, the carcass was chopped into fragments with sharp scissors inside the crucible and then dried to constant weight at $105^{\circ}$ to determine the moisture content. With these small animals the whole dried remains were then transferred to a dried weighed Soxhlet thimble and extracted with hot ether for 5-6 hr. The ether was allowed to evaporate from the thimble, the contents were re-dried at $105^{\circ}$, cooled in a desiccator and again weighed so that the fat-free dry weight and fat content of the body might be obtained. It was found possible to grind the dry remains to a powder, large portions of which were taken for determinations of nitrogen by the macro-Kjeldahl procedure, and of the ash by incineration in a small muffle furnace. Duplicate determinations showed good agreement.

This procedure was repeated with the remaining rats at the end of the experimental period of 7 weeks. With groups 2 and 3 which received the diets containing the 80 and $85 \%$ extraction flours, the six rats of each group were dealt with together on the 48 th day. They were minced and dried in a large pyrex dish, subsequent operations being performed on large representative portions. The rats of groups I and 4 , which received diets with flours of 70 and $100 \%$ extraction, were dealt with individually on the 49 th day, a much larger Soxhlet extraction apparatus being used than before.

\section{RESULTS}

The results obtained for the eight rats killed at the beginning of the experiment and for the six rats each on the white flour and wholemeal diets, are reported in full in Table I, which shows the percentage content of water, fat, nitrogen and ash on the basis of fresh empty weight. The average figures obtained for each group, including those for the six rats each on the diets containing 80 and $85 \%$ flours which were dealt with together, are summarized in Table 2. The most significant feature of these results is the almost uniform content of protein $(\mathrm{N} \times 6)^{*}$, not only in the rats within each group but shown by the average values for the different groups. From the figures in Table I the sum of fat, water, ash and protein amounts to about $99 \%$ of the body-weight, suggesting that little carbohydrate material was stored in the bodies of the animals.

Statistical analysis of the results showed no significant difference in protein content between the weanling rats of average empty weight $42 \cdot 7 \mathrm{~g}$. which were killed initially (with average protein content of $16.7 \%$ ) and rats of average empty weight $87 \mathrm{~g}$. (with average protein content of $17 \cdot 2 \%$ ), which had received the diet containing white $70 \%$ extraction flour for 7 weeks. For the rats of average empty weight $120 \mathrm{~g}$., which had received the whole-wheat flour diet for 7 weeks, the protein content of $17.4 \%$ showed a barely significant difference from that of the weanling group.

The percentage content of ash in the rats in the four groups killed at the end of the experiment was a little higher than that of the weanling rats. The figures for the percentage fat content of the different groups showed that the larger animals had a higher content. The increase in fat content with increase in body-weight was

- The factor 6 is adopted in place of the usual 6.25 to allow for the small amount of non-protein nitrogen. 
ษ

.

รี है

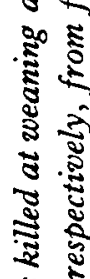

ชั่

赵.

2

胥

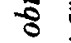

छे हे

胥

$\therefore i^{\circ}$

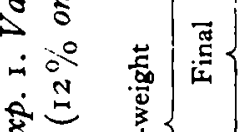

每.

$\Xi \Xi$

|

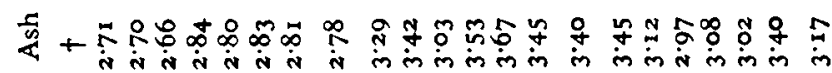

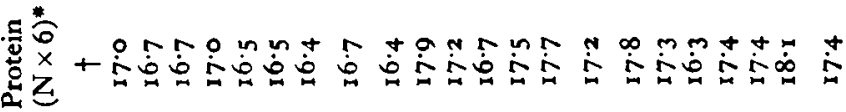

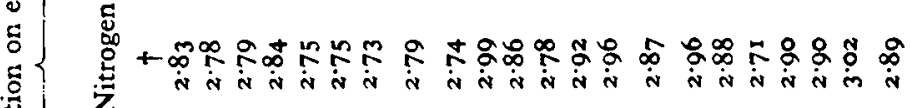

L ก no

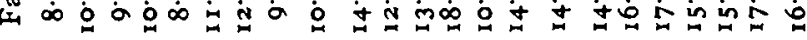

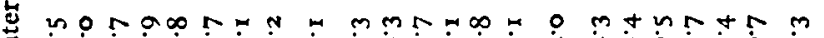

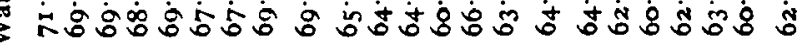

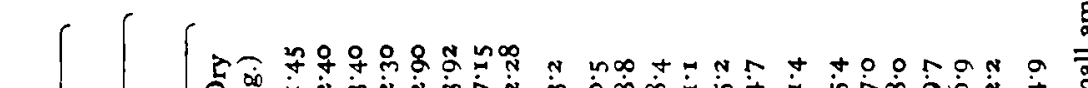
政

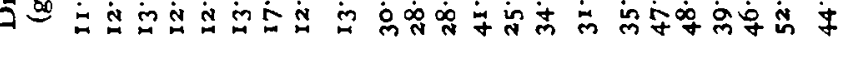

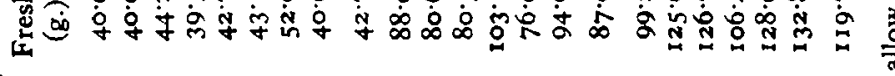

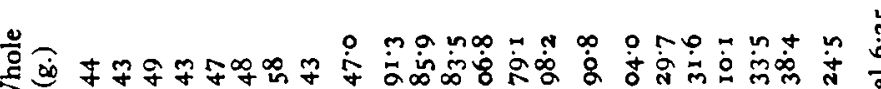
ֻ.

$+2$

要票

$\frac{2}{2 \cdot \frac{2}{2}}$

के

30

.$\frac{2}{2}$

U

के

赵

$\Im 5$

a

उั้

它范

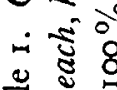

需 3

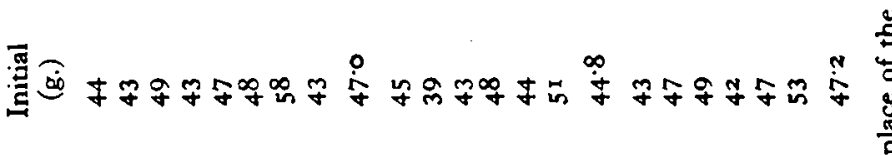

intoris

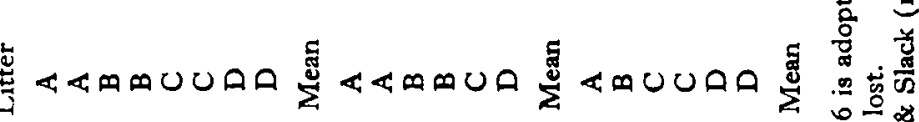

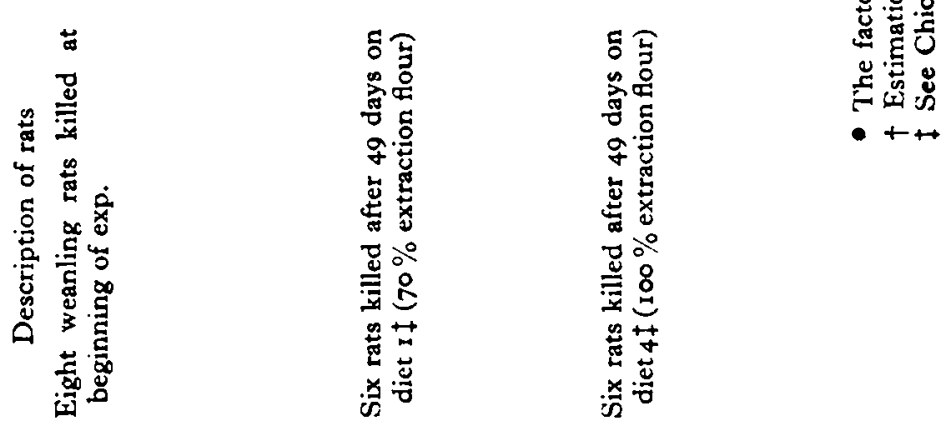


accompanied by an equivalent decrease in percentage water content, thus accounting for the relatively uniform percentage content of protein in the rats of all groups.

These results are shown in Fig. I, in which are charted the figures for percentage content of water, fat, protein and ash in the bodies of individual rats in the initial group and in the groups which received for 7 weeks the diets containing the flours of 70 and $100 \%$ extraction. The average figures for the rats receiving diets containing

Table 2. Average composition of rats killed at weaning or maintained for 7 weeks on diets in which the protein (12\% on dry weight) was supplied by wheat flours of different percentage extraction

\begin{tabular}{|c|c|c|c|c|c|c|c|c|c|}
\hline \multirow[b]{2}{*}{$\begin{array}{l}\text { Diet } \\
\text { no. }\end{array}$} & \multirow[b]{2}{*}{$\begin{array}{l}\text { Source of } \\
\text { nitrogen }\end{array}$} & \multirow{2}{*}{$\begin{array}{l}\text { No. } \\
\text { of } \\
\text { rats }\end{array}$} & \multicolumn{2}{|c|}{ Empty weight } & \multicolumn{5}{|c|}{$\begin{array}{l}\text { Average percentage composition on empty } \\
\text { fresh weight }\end{array}$} \\
\hline & & & $\begin{array}{l}\text { Original } \\
\text { (g.) }\end{array}$ & $\begin{array}{l}\text { Final } \\
\text { (g.) }\end{array}$ & Water & Fat & $\begin{array}{l}\text { Nitro- } \\
\text { gen }\end{array}$ & $\begin{array}{l}\text { Protein } \\
(N \times 6)\end{array}$ & Ash \\
\hline Stock & diet & 8 & $42 \cdot 7$ & $42 \cdot 7$ & $69 \cdot x \pm 0.5$ & $10.1 \pm 0.5$ & $2 \cdot 79$ & $16.7 \pm 0.08$ & $2.78 \pm 0.03$ \\
\hline I & $\begin{array}{l}70 \% \text { extraction } \\
\text { flour }\end{array}$ & 6 & $40.7 \dagger$ & $87 \cdot 0$ & $64 \cdot 0 \pm 0.9$ & $14 \cdot 2 \pm 1 \cdot 1$ & 2.87 & $17.2 \pm 0.24$ & $3.40 \pm 0.09$ \\
\hline 2 & $\begin{array}{l}80 \% \text { extraction } \\
\text { flour }\end{array}$ & 6 & $41 \cdot 5 t$ & $9 \pi \cdot 5 \ddagger$ & $64 \cdot 3$ & 14.5 & $2 \cdot 75$ & $16 \cdot 5$ & 3.39 \\
\hline 3 & $\begin{array}{l}85 \% \text { extraction } \\
\text { flour }\end{array}$ & 6 & $4 I \cdot 2 \dagger$ & $102 \cdot 8 t$ & $63 \cdot 5$ & $15 \cdot 3$ & $2 \cdot 75$ & 16.5 & $63 \cdot 27$ \\
\hline 4 & $\begin{array}{l}100 \% \text { extraction } \\
\text { flour }\end{array}$ & 6 & $42 \cdot 8+$ & $119 \cdot 7$ & $62 \cdot 3 \pm 0 \cdot 6$ & $16 \cdot 1 \pm 0.5$ & $2 \cdot 89$ & $17.4 \pm 0.25$ & $3.17 \pm 0.08$ \\
\hline
\end{tabular}

- Values with their standard errors of the mean, except for diets 2 and 3 since the rats which received these diets were analysed together (see p. 215).

+ Calculated from figures obtained for litter-mates killed at beginning of experiment.

$\ddagger$ On 48th day.

80 and $85 \%$ extraction flours are also inserted. The general trend for loss of water, gain of fat and constancy of protein with increasing body-weight is clearly shown. Between body-weights of 40 and $140 \mathrm{~g}$. the percentage loss in water was about 9 and the gain in fat about 8 . It should be noted that in Table $\mathrm{I}$, figures refer to analysis of the empty body and in Fig. I empty body-weight is plotted. In the determination of P.E.R., however, the whole body-weight is measured. Nevertheless, since the ratio: whole body-weight/empty body-weight was reasonably constant, varying only from $\mathrm{I} \cdot \mathrm{IO}$ for rats of average weight $47 \mathrm{~g}$. to $\mathrm{I} \cdot 04$ for those of average weight $124 \mathrm{~g}$., one may conclude that the percentage of protein remains constant when reckoned on the ordinary body-weight.

These results are in general agreement with those obtained by Mitchell \& Carman (1926) and Pickens, Anderson \& Smith (1940), who obtained roughly comparable figures for the percentage composition of rat carcasses. A more detailed comparison with the results of these two groups of authors is not possible since they did not employ diets comparable with those used by Chick \& Slack (1948). Mitchell \& Carman, who analysed at different ages between 33 and 188 days the bodies of rats receiving a complete diet, found very wide differences in composition even amongst a group of nine rats killed at the beginning of their experiment. Pickens et al. obtained rather 
more consistent results with groups of rats that were analysed after having received complete or protein-deficient diets for periods of up to $25^{\circ}$ days. They found that: 'With a few exceptions the proportion of fat increased and that of water declined with increasing age. No striking relationship was noted between age and the proportion of protein or ash in the gains.' The greater uniformity of composition of the rats used

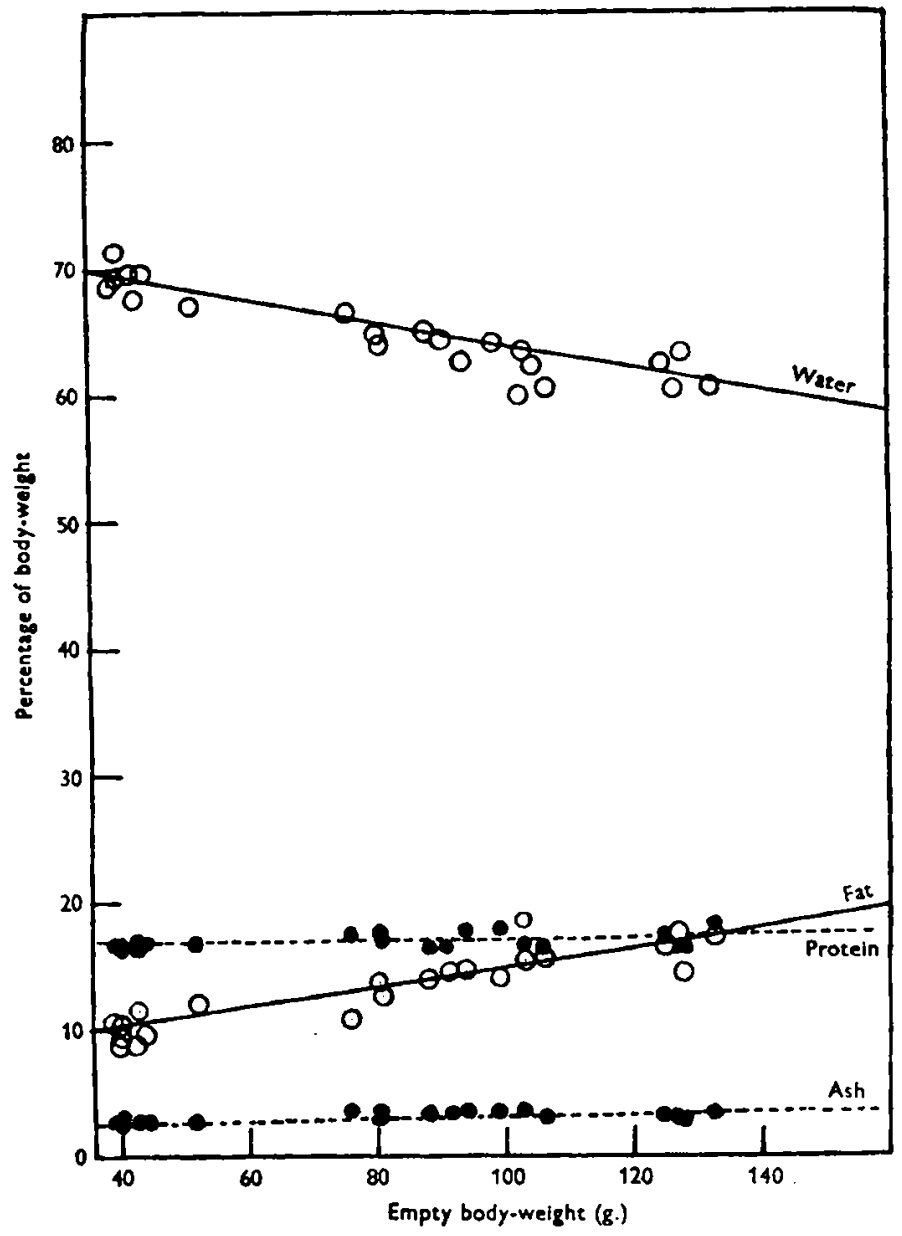

Fig. 1. Percentage of water, fat, protein and ash in bodies of rats weighing $40-140 \mathrm{~g}$.; those over $50 \mathrm{~g}$. were fed on diets in which the protein, suboptimal in amount, was derived from wheat flours of different percentage extraction (see Tables 1 and 2 ); curves fitted by eye.

in the present experiment can partly be attributed to the special attention paid to the breeding and selection of rats for experiment in the Lister colony and partly to the fact that the rats were of the same age and, though of different body-weight, still at about the same stage of development.

The purpose of the present experiment was to determine whether, within the period and under the conditions in which determination of P.E.R. may most satisfactorily be made, increase in weight is a valid guide to bodily retention of protein, and was not concerned, 
as was the work of the other investigators, with the composition of the gain in weight of rats approaching maturity.

From the data collected in Table $\mathbf{I}$ it was possible to calculate the percentage of the nitrogen eaten and digested that was retained in the bodies of the animals. The figures obtained on the litter-mates at the beginning of the experiment enabled a calculation to be made of the initial empty weight and nitrogen content of the rats in the four groups which received the different diets. As the final empty weight and nitrogen content of these rats was known, the increase in body nitrogen could be determined and related to the amount of nitrogen eaten and digested. These values, expressed in terms of average individual values for each group, are presented in Table 3 and relate to the

Table 3. Bodily retention of nitrogen in rats maintained for 49 days on diets in which the protein was supplied by wheat flours of different percentage extraction. Mean values for groups of six rats

\begin{tabular}{|c|c|c|c|c|c|c|c|c|c|c|c|}
\hline \multirow[b]{2}{*}{$\begin{array}{l}\text { Diet } \\
\text { no. }\end{array}$} & \multirow[b]{2}{*}{$\begin{array}{c}\text { Percentage } \\
\text { extraction } \\
\text { of flour }\end{array}$} & \multicolumn{2}{|c|}{ Empty weight } & \multirow[b]{2}{*}{$\begin{array}{c}\text { Weight } \\
\text { increase } \\
\text { (g.) }\end{array}$} & \multicolumn{2}{|c|}{ Nitrogen content } & \multirow{2}{*}{$\begin{array}{l}\text { Nitrogen } \\
\text { eaten } \\
\text { (g.) }\end{array}$} & \multirow{2}{*}{$\begin{array}{c}\text { Coefficient } \\
\text { of apparent } \\
\text { digestibility } \\
\text { of nitrogen } \\
(\%)\end{array}$} & \multicolumn{3}{|c|}{ Percentage retention of } \\
\hline & & $\overbrace{\substack{\text { Original } \\
\text { (g.) }}}^{*}$ & $\begin{array}{c}\text { Final is } \\
\text { (g.) }\end{array}$ & & $\overbrace{\begin{array}{c}\text { Original } \\
\text { (g.) }\end{array}}$ & $\begin{array}{c}\text { Final } \\
(\mathrm{g} .)\end{array}$ & & & $\begin{array}{c}\text { Nitrogen } \\
\text { absorbed } \\
\text { (g.) }\end{array}$ & $\begin{array}{c}\text { Nitrogen } \\
\text { eaten }\end{array}$ & $\begin{array}{l}\text { Nitrogen } \\
\text { absorbed }\end{array}$ \\
\hline $\mathbf{I}$ & 70 & $40 \cdot 7$ & $87 \cdot 0$ & $46 \cdot 3$ & I. 14 & $2 \cdot 50$ & 5.99 & $88 \cdot 8$ & $5 \cdot 32$ & $22 \cdot 9$ & 25.9 \\
\hline 2 & 80 & $41^{\circ}$ & $92 \cdot 5 \dagger$ & $+5 x \cdot 0$ & $I \cdot I$ & & & 86 & 5 & 22 & \\
\hline 3 & 85 & 41 & $104.2 \dagger$ & $\dagger 63.0$ & $1 \cdot 1$ & 2.8 & & & & & \\
\hline 4 & 100 & 42.8 & 119.7 & 76.9 & $1 \cdot 20$ & $3 \cdot 46$ & $8 \cdot 46$ & $81 \cdot 0$ & $6 \cdot 85$ & $26 \cdot 7$ & $33^{\circ} 0$ \\
\hline
\end{tabular}

- Calculated from figures obtained for litter-mates killed at beginning of experiment.

+ Calculated from 'empty' weight on 48 th day.

full experimental period of 49 days, a slight correction being made to the figures for groups 2 and 3 for which the experimental period was 48 days. There was no significant difference in the proportion retained of nitrogen eaten from the diets containing 70 and $80 \%$ extraction flours, the figures being 22.9 and $22.1 \%$ respectively. The proportion retained from the diets containing 85 and $100 \%$ extraction flour was definitely higher, the respective figures being 24.6 and $26.7 \%$. The coefficients of digestibility found for the nitrogen of the four flours were $88 \cdot 8,86 \cdot 7,85 \cdot 5$ and $8 \mathrm{I} \cdot 0 \%$ respectively (see Chick \& Slack, 1948). The proportion retained of the nitrogen absorbed from the four flours, was respectively, $25.9,25.5,28.8$ and $33.0 \%$.

The general conclusion to be drawn is that the proteins contained in flours of $7 \circ$ and $80 \%$ extraction are about equally efficient for building the tissues of the growing rat, but that those of 85 and $100 \%$ extraction flour are superior in value by about 9 and $19 \%$ respectively. If these figures are reckoned on the amounts of protein absorbed they become 12 and $28 \%$ respectively.

\section{SUMMARY}

I. Determinations were made of the content of water, fat, nitrogen and ash in the bodies of groups of litter-mate rats maintained for 7 weeks from weaning on diets containing about $12 \%$ of protein derived, respectively, from $70,80,85$ and $100 \%$ extraction flours. The initial composition of the rats was calculated from results of 
similar analyses made on litter-mates killed at the beginning of the experiment. From these figures the total retention of nitrogen in each group was calculated. The average percentage retention of the nitrogen eaten was $22 \cdot 9,22 \cdot 1,24.6$ and 26.7 respectively for the rats receiving $70,80,85$ and $100 \%$ extraction flours; the corresponding figures for the retention of the nitrogen which was absorbed were $25.9,25.5,28.8$ and $33.0 \%$ respectively. The greater nutritive value of the proteins in the flours of higher percentage extraction obviously more than compensated for their lower digestibility.

2. Under the conditions of the experiment the fat content of the experimental rats increased, and the water content decreased, with increasing body-weight. These changes were of roughly equal magnitude, and the percentage of protein and ash remained approximately constant in each group.

3. Since, under the conditions of the experiment, gain in protein was proportional to gain in body-weight, the values obtained for the protein efficiency ratio (P.E.R.) of the protein tested provided a reliable means of comparison of their nutritive value.

I wish to thank $\mathrm{Dr} \mathrm{K}$. H. Coward for her help and advice in the statistical consideration of the results, $\mathrm{Dr} \mathrm{H}$. Chick for co-operation in the animal work and for making the determinations of ash content, and Sir Charles Martin for his invaluable encouragement and helpful criticism at all times.

\section{REFERENCES}

Chick, H. \& Slack, E. B. (1948). Brit. F. Nutrit. 2, 205.

McCollum, E. V. \& Simmonds, N. (1929). The Nezier Knowledge of Nutrition, 4th ed. New York: The Macmillan Co.

Mitchell, H. H. (1924). Physiol. Rev. 4. 424.

Mitchell, H. H. \& Carman, G. G. (1926). Amer. F. Physiol. 76, 398.

Osborne, T. B., Mendel, L. B. \& Ferry, E. L. (1919). F. biol. Chem. 37, 223.

Pickens, M., Anderson, W. E. \& Smith, A. H. (1940). F. Nutrit. 20, 351. 